\title{
COMPLEX WOUNDS
}

Marcus Castro Ferreira', Paulo Tuma Júnior ${ }^{1}$, Viviane Fernandes Carvalho', Fábio Kamamoto ${ }^{2}$

Ferreira MC, Tuma Jr. P, Carvalho VF, Kamamoto F. Complex wounds. Clinics. 2006;61(6):571-8.

Complex wound is the term used more recently to group those well-known difficult wounds, either chronic or acute, that challenge medical and nursing teams. They defy cure using conventional and simple "dressings" therapy and currently have a major socioeconomic impact. The purpose of this review is to bring these wounds to the attention of the health-care community, suggesting that they should be treated by multidisciplinary teams in specialized hospital centers. In most cases, surgical treatment is unavoidable, because the extent of skin and subcutaneous tissue loss requires reconstruction with grafts and flaps. New technologies, such as the negative pressure device, should be introduced. A brief review is provided of the major groups of complex wounds-diabetic wounds, pressure sores, chronic venous ulcers, post-infection soft-tissue gangrenes, and ulcers resulting from vasculitis.

KEYWORDS: Complex wounds. Socioeconomic impact. Surgical treatment. Skin grafting. Skin flaps.

Expectancy of a longer life is recognized as one of major contributions afforded by modern civilization; however, improvement of quality of life has not necessarily followed that increase in life years. On the contrary, older populations may develop problems related to longevity that can compromise their quality of life.

Losses of cutaneous integument, represented not only by skin disruption but also by loss of subcutaneous tissues, sometimes including even muscle and bone, have been generally defined in medical textbooks as "wounds". There are striking differences between simple wounds, for example surgical wounds or skin scratches, and those chronic wounds that do not heal primarily and demand specialized care, mostly in hospitals. However, the latter have not merited enough attention by surgeons who consider the treatment of wounds to be a less sophisticated aspect of the profession, and consequently of no special interest.

More recently, the increasing number of aged patients and the frequency of these more difficult wounds has started

${ }^{1}$ Division of Plastic Surgery, Hospital das Clínicas, São Paulo University Medical School - São Paulo/SP, Brazil.

${ }^{2}$ Hospital Universitário, University of São Paulo - São Paulo/SP, Brazil. Email: mcferrei@uol.com.br

Received for publication on October 13, 2006.

Accepted for publication on October 16, 2006. to attract the attention not only of doctors and nurses but also of health-care administrators worried about the impact of the cost of these wounds on their hospital budgets.

In Brazil, the topic has not attained widespread interest, but in the State of São Paulo and in particular in Hospital das Clínicas of São Paulo University Medical College, the problem is gaining more importance in this new century.

A proposal was made by a group working at the Division of Plastic Surgery of the Institution to form a multidisciplinary group including doctors (plastic and vascular surgeons, dermatologists) and wound therapy nurses. ${ }^{1}$ It was formally approved in 2006, and its main goal is the study of the so-called "complex wounds".

But what are complex wounds?

There is not as yet a clear definition of complex wounds or specific criteria to separate them from the simpler ones. The term "chronic wounds", although frequently used, means only that more time was needed up to the cure, but it is not good enough a concept to characterize the complexity of the problem. We could use "difficult wounds" (in Portuguese, feridas difíceis), as proposed in German, (schwierige Wunde), but we prefer to use the term "complex wounds" (feridas complexas) in order to encompass the different criteria for classifying these special wounds 
and the challenge they pose for medical and nursing teams.

One or more of the following conditions must be present for a wound to be categorized as a "complex" type:

1 - Extensive loss of the integument is an important criterion, whether it is an acute or chronic wound. Chronic wounds are defined as wounds that have not healed expontaneously in 3 months $^{2}$ and usually have a common pattern of the complexity.

2 - Infection is frequently present as a complication in chronic wounds and in itself may be the cause of the problem that resulted in tissue loss, as happens in aggressive infections like Fournier's gangrene.

3 - Compromised viability of superficial tissues-clear necrosis, or signs of circulation impairment either localized or more extensive, usually in the limbs, leading to extensive loss of substance.

4 -Association with systemic pathologies that impair normal healing causing wounds to fail to heal with simple care and requiring special attention. Feet ulcers in diabetic patients and many forms of vasculitis are common examples.

We thus consider the most commonly seen complex wounds, needing special care by a specialized group, as the following:

1 - Wounds in the lower extremity of diabetic patients,

2 - Pressure ulcers,

3 - Chronic venous ulcers,

4 - Wounds following extensive necrotic processes caused by infections (Fournier's and other), and

5 - Chronic wounds related to vasculitis and immunosuppressive therapy that have not healed using simple care.

Burns might be included in this group of complex wounds (and indeed they are, in many instances, very complex wounds), but tradionally they are separated from this group, basically because burns have been regarded for some time to be a special condition that should be treated in specialized burn centers.

Using these concepts, over the last 5 years we have established measures to ensure a better understanding of the prevalence of these complex wounds in our institution (including the establishment of an electronic database) and to study and revise the procedures usually used to treat them, ie, dressings, surgical options, and new technologies that have recently become available, such as the negative pressure on wounds (vacuum systems).

It has already become clear to us that these complex wounds should usually be treated using surgical procedures instead of leaving them to clinical and expectant measures. Additionally, débridements, skin grafting, and flap coverage should be indicated sooner than has been done traditionally.
Determining that the majority of these complex wounds should be considered "surgical cases" and not just "cases for dressings" surely represents the major turning point of a new policy to provide more stable coverage of the wounds, thus improving the quality of life. It should reduce the time of hospitalization and the cost of treatment. Preventative measures are also essential.

Complex wounds will be briefly reviewed, and main factors of policies that will produce faster and stable closure of these wounds-awareness of the importance for the health-care system, complexity of the treatment, and current best surgical approaches_-will be emphasized.

\section{Wounds in diabetic patients}

It is well known that diabetes mellitus is a chronic multifactorial disease. Global prevalence of diabetes was 120 million in 1996, but predictions for 2030 suggests values as high as 366 million, due to longer life expectancies, obesity, and sedentary life styles. ${ }^{3,4,5}$ In Brazil, the diabetic population is estimated to be approsimately 10 million. ${ }^{6}$ In 2001 , persons throughout Brazil who were 40 years old or older were invited to participate in community screening for diabetes as part of the Brazilian Ministry of Health's Plan for the Reorganization of Care for Arterial Hypertension and Diabetes Mellitus. Of the 30.2 million persons in the target population, 22.1 million $(73.0 \%)$ were examined, and 3.5 million tested (15.7\%) positive for elevated blood glucose levels. ${ }^{7}$

Among the complications that most frequently affect the diabetic individual are cardio-, retino-, and nephropathies; however, wounds in the lower extremity also are a major burden for the patient and health system. ${ }^{8,9,10}$

Such wounds are usually chronic, mostly in the feet, and treatment is difficult; all too often, these wounds do not heal primarily. ${ }^{11,12}$ Simple control of glucose blood levels, although important, is not necessarily followed by healing these ulcers. ${ }^{13,14}$ Frequently, wounds evolve with extensive necrosis and infectious processes that may lead to amputation of body parts, even of limbs..$^{15,16,17,18}$

Obstruction of major blood vessels is responsible for less that $30 \%$ of the wounds; today, the main recognized cause is the neuropathy of diabetes, ${ }^{19,20,21}$ the progressive degeneration of the sensitive nerves of the foot induced by microangiopathy of the small vessels to the nerve fascicles and in many cases associated with external compression at some anatomical sites, as in the tarsal tunnel. ${ }^{22,23,24}$

Patients develop a progressive loss of sensation on their lower extremities, and because of that, they do not perceive small traumas on their feet, resulting in a chronic ulcer with a lower potential for healing due to the microangiopathic disease. ${ }^{25,26,27}$ 
Modern treatment of this pathology includes evaluation not only of the vascular status, ${ }^{28,29,30}$ but also of the neuropathy, using more precise tests to assess the sensibility of the feet, ${ }^{31}$ such as the PSSD ${ }^{\mathrm{TM}}$ (Pressure Specified Sensory Device) described by Lee Dellon of Baltimore ${ }^{32}$; in use at the Hospital das Clínicas. ${ }^{33}$

This wound should be treated surgically and as soon as possible, removing necrotic tissues ${ }^{34,35,36}$ and providing wound bed preparation ${ }^{37,38}$ using specific dressings ${ }^{39,40}$ or negative pressure $e^{41,42,43}$ (vacuum devices). Closure should be achieved as soon as possible with skin grafting, ${ }^{44,45,46}$ local flaps, ${ }^{47,48,49,50}$ or microsurgical flaps. ${ }^{51,52,53}$

With these measures, we expect to reduce the significant personal and economic costs caused by the "diabetic foot"- the resulting longer stay in hospital, longer rehabilitation, and need for special care. Amputations should be avoided at all costs, as they are no longer the only alternative for treatment of the ulcer after failure of conservative measures to heal the ulcer, even if associated with complications like osteomyelits. ${ }^{54,55}$

Primary healing in the USA is estimated to cost between US\$ 7,000 and US\$10,000 per person, but the overall cost of an amputation related to the diabetic foot is estimated between 4.6 and 13.7 billion dollars. ${ }^{56}$

Costs in Brazil for the treatment of these patients are not known, but due to the notorious deficiencies in our health system, they must be very high, and worse, they signify a major burden for patients and their families.

\section{Pressure sores}

Many patients today need a long period of hospitalization for the treatment of chronic illnesses; typically they are old and have limitations in their normal movements. In this context, we come across pressure wounds, also known as pressure sores which represent a significant challenge for health professionals..$^{57,58}$

A pressure sore is defined as an area of necrosis in the integument developed as a result of compression of soft tissues between an osseous prominence and a hard surface during a sufficiently long period of time to induce local ischemia. ${ }^{59}$

Patients with pressure sores have extended dependency on their caretakers, higher mortality, and lower quality of life. Pressure sores increase hospitalization time and the overall cost of treatment. ${ }^{60}$

Accordingly to the National Pressure Ulcer Advisory Panel, a US agency that coordinates actions for prevention and treatment of pressure sores, prevalence in hospitals in the USA varies from $3 \%$ to $14 \%$, increasing to $15 \%$ to $25 \%$ in nursing homes. ${ }^{61}$ The incidence reported by Bergstrom et $\mathrm{al}^{62}$ in home care was $23.9 \%$. In a study performed by São Paulo University at its Hospital Universitário, the incidence was $39.5 \%$ in surgical units, but higher, $41 \%$, in intensive care units. ${ }^{63}$

The incidence and prevalence of pressure sores has grown due to the increase in patient age and lower mortality in high-complexity surgeries. It is our impression that in São Paulo it has also grown due to a decrease in the quality of care and prevention, especially in intensive care units.

Although the problem of diabetic wounds is very extensive but not well quantified in Brazil, the problem caused by excessive pressure sores in bedridden patients should be simpler to evaluate, and measures to identify the potential cases for developing pressure sores should be put in practice, especially because we know that these preventative procedures are most important in the overall care of the patients.

Unfortunately, policies for preventative measures to avoid the development of complex wounds have not been implemented in Brazil, and we are seeing more and more cases in our hospitals, in addition to many recurrences of already treated ulcers.

Hospital das Clínicas comprises for Institutes, the largest being the Central Institute, with 920 beds. On average we have 40 patients with pressure sores-about $5 \%$, a figure similar to the international standard. Specific evaluation of the severity of those ulcers is currently being done, aided by the use of electronic databases.

Our proposal is to treat such cases as they are identified, but to also take into account that the treatment should more prompt than that in the conventional expectant orientation. Surgical treatment is the main option, and includes debridement of necrotic tissues, use of negative pressure ${ }^{64}$ (vacuum) to better prepare the wound bed, and providing definite closure with stable transplants, mostly local, wellvascularized transplants. ${ }^{65}$

Prevention must be enforced using well-known scale protocols already reported. The Braden scale is the most popular in our hospitals, and it has been translated into Portuguese. ${ }^{66}$ These protocols are very important for prevention of ulcers in higher-risk patients, but even after the closure of the sore, rehabilitation should be instituted in order to prevent recurrences.

\section{Chronic venous ulcers}

Described by Hippocrates more than 2,000 years ago, ${ }^{67}$ chronic venous ulceration is not generally considered a "curable" disease. Venous stasis ulceration is a frequent clinical condition causing considerable morbidity, poor quality of life, ${ }^{68}$ and significant socioeconomic loss. ${ }^{69}$ 
Chronic venous ulcers are considered to be the most common disorder of vascular origin. ${ }^{70,71}$ The chronic ulcer is caused by chronic venous insufficiency in the lower extremity, but it is frequently aggravated by scarring processes in the surrounding skin and subcutaneous tissues that render treatment of the ulcer by conventional measures slow and that leave tissues prone to recurrences. ${ }^{72}$

Definite treatment of venous insuffiency is not possible with the presently available technology. ${ }^{73,74,75}$ Measures to alleviate the insuffiency should be performed when indicated; but in order to solve the problem of the chronic wound, a more aggressive surgical protocol should aim to remove the lipodermatosclerotic tissues and to reconstruct the area with tissues that could bring venous channels to alleviate the stasis. ${ }^{76,77,78,79}$

Venous ulcers are frequent, approximately $0.06 \%$ to $1.5 \%$ nationally and and internationally. ${ }^{80,81,82}$ The problem is universally severe, and there is a considerable economic impact. . $^{83,84}$

The etiology and pathophysiology of chronic venous ulcers are still incompletely understood. The most common treatment options include prolonged bed rest, Unna's boot, ${ }^{85}$ local wound care, ${ }^{86,87,88}$ and skin grafting..$^{89,90} \mathrm{We}$ are evaluating modern dressings that can be used for this condition and prevent complications. ${ }^{91}$

The importance of the role of skin grafting resilience and its potential to prevent recurrence is being evaluated, as is that of local and distant flaps used in more severe cases of recalcitrant ulcers after removal of the lipodermatosclerotic tissues. ${ }^{92,93}$

Vein stripping and perforator ligation valvuloplasty may improve regional venous hemodynamics and are often indicated by vascular surgeons, but they do not solve the problem of the wound if there is irreversible scarring due to surrounding lipodermatosclerosis.

For these reasons, we have categorized chronic venous ulcers as complex wounds in order to study dressings and other new ways to treat these wounds as well as the relevance of some surgical procedures being developed in the USA, including the use of new local flaps and even microsurgical transplants to more permanently close the difficult wounds. ${ }^{68}$

\section{Extensive necrotic gangrene as in Fournier's syndrome}

Fournier's gangrene is an infectious necrotizing fasciitis of the perineum and genital regions caused by a mixture of aerobic and anaerobic organisms. The mortality rate from this infection ranges from $0 \%$ to $67 \% .^{94}$ The outcome is usually fatal if there is no early recognition and extensive surgical debridement upon initial diagnosis. ${ }^{95}$ This should be followed by aggressive antibiotic therapy combined with other precautionary and resuscitative measures. It is well know that early aggressive surgical debridement combined with broad-spectrum antibiotic coverage results in decreased mortality from Fournier's gangrene and other forms of extensive necrotic fasciitis.

Fournier's gangrene occurs in male and female patients with genital abscesses, cellulitis, necrotizing fasciitis, and vascular disorders; it is more frequent in males than in females. ${ }^{92}$

Precautionary measures are important for supporting the patient with Fournier's gangrene as are urinary and fecal diversions when necessary. Treatment with hyperbaric oxygen is still controversial as a complementary treatment to débridements, although some have claimed advantages with its use. ${ }^{96}$

In the Hospital das Clínicas, São Paulo, aggressive débridements have been used for more than 15 years, and the mortality rate has declined impressively. ${ }^{97,98}$

However, there are not many articles related to the reconstruction after the removal of skin and subcutaneous tissue that sometimes are quite extensive, and the wound is usually not amenable to direct closure.

In order to reduce the hospitalization time, we operate to reconstruct these patients promptly, use negative pressure (vacuum) for faster preparation of the wound bed, and use skin grafting to close the wound.

Later, reconstruction using flaps for functional (coverage of testicles) and for aesthetic proposes are done at under ambulatory conditions.

\section{Wounds in patients with autoimmune disease or under immunosuppressive drug therapy-vasculitis}

Wounds in patients with severe systemic chronic diseases seem to have risen in number as hospital care for these diseases has improved. Extensive ulcers that could be considered complex wounds are not frequent, but they may be an important cause for longer hospitalization time and for rising costs of treatment; consequently, they need special consideration.

We have seen a number of those wounds related to autoimmune diseases such as in rheumatoid arthritis and related to immunosuppressive drugs, mostly in transplant patients, and even in less known entities such as pyoderma gangrenosum. The common pathophysiologic link seems to be some form of "vasculitis", which acts in the peripheral vessels of the superficial tissues and leads to an inflammatory process, capillary occlusion, and necrosis of tissues. ${ }^{99}$

The necrotic area is sometimes not well defined, and 
sometimes the surgical debridement can induce new areas of inflammatory process that enlarge the area. Corticosteroids may have a positive effect in controlling the basic problem of vasculitis. Its well-known negative influence on wound healing seems to be less important if a reconstructive procedure like a flap or graft is used.

Recent studies on reconstructive surgery for immunosuppressed organ transplantation patients have shown that no serious deficit of healing was observed, which was also observed with reconstruction after tumor removal and chemotherapy. ${ }^{100}$ There is clear evidence that such wounds should not be treated conservatively but rather included in this group of complex wounds and treated accordingly in wound centers.

Pyoderma gangrenosum, a cutaneous ulcer with no clear etiology, represents well the difficulties of treating these special wounds caused by vasculitis. It can have different clinical presentations and is often associated with inflammatory intestinal disease (55\%) and rheumatoid arthritis $(37 \%) .{ }^{101}$ It can be associated with plastic surgeries including aesthetic ones, particularly in the breast. ${ }^{102}$

Our experience is not extensive enough to draw any conclusion about the best treatment available, but apart of the appropriate medical systemic treatment for the general condition, the wound should be treated by removal of necrotic tissue and surrounding tissue of doubtful viability, preparation of the bed, and closure as soon as possible with skin grafting techniques.

Use of adjunctive therapies, such as hyperbaric oxygen therapy, has not proven its value, and it is not presently recommended by our group.

Multidisciplinary care of the patient is essential. ${ }^{103}$

\section{RESUMO}

Ferreira MC, Tuma Jr. P, Carvalho VF, Kamamoto F. Feridas complexas. Clinics. 2006;61(6):571-8.

Ferida complexa é uma nova definição para identificar aquelas feridas crônicas e algumas agudas já bem conhecidas e que desafiam equipes médicas e de enfermagem. São difíceis de serem resolvidas usando tratamentos convencionais e simples curativos. Têm atualmente grande impacto sócio-econômico. Esta revisão procura atrair atenção da comunidade de profissionais de saúde para estas feridas, sugerindo que devam ser tratadas por equipe multidisciplinar em centro hospitalar especializado. Na maioria dos casos o tratamento cirúrgico deve ser indicado, uma vez que a perda de pele e tecido subcutâneo é extensa, necessitando de reconstrução com enxertos e retalhos. Nova tecnologia, como uso da terapia por pressão negativa foi introduzido. Breves comentários sobre os principais grupos de feridas complexas: pé diabético, úlceras por pressão, úlceras venosas, síndrome de Fournier e vasculites.

UNITERMOS: Feridas complexas. Impacto sócioeconômico. Tratamento cirúrgico. Enxertos de pele. Retalhos cutâneos.

\section{REFERENCES}

1 Gottrup F. A specialized wound-healing center concept: importance of a multidisciplinary department structure and surgical treatment facilities in the treatment of chronic wounds. Am J Surg. 2004;187:38S-43S.

2 Harding KG, Morris HL, Patel GK. Science, medicine and the future: healing chronic wounds. BMJ. 2002;324:160-3.

3 Wild S, Roglic G, Green A, Sicree R, King H. Global prevalences of diabetes. Estimates for the year 2000 and projections for 2030. Diabetes Care. 2004;27:1047-53.

4 Boulton AJ, Vileikyte L, Ragnason-Gennvall, Alpelqvist J. The global burden of diabetic foot disease. Lancet. 2005;306:1719-24.

5 Apelqvist J, Ragnarson-Tennvall G, Larsson J, Persson U . Long term costs in a multidisciplinary setting. Foot and Ankle. 1995;16:388-94.
6 Malerbi DA, Franco LJ. Multicenter study of the prevalence of diabetes mellitus and impaired glucose tolerance in the urban population aged 30-69. The Brazilian Cooperative Group on the study of diabetes prevalence. Diabetes Care. 1992;15:1509-16.

7 Nucci LB, Toscano CM, Maia ALM, Fonseca CD, Britto MMB, Duncan $\mathrm{BB}$, et al. A nationwide population screening program for diabetes in Brazil. Ver Panam Salud Publica. 2004;16:320-7.

8 Singh N, Armstrong DG, Lipsy BA. Preventing foot ulcers in patients with diabetes. JAMA. 2005;293:217-28.

9 Cavanagh PR, Lipsky BA, Bradbury AW, Botek G. Treatment for diabetic foot ulcers. Lancet. 2005;366:1725-35.

10 Ragnarsson-Tennvall G, Apelqvist J. Cost-effective management of diabetic foot ulcers. Pharmaco Economics. 1997;12:42-53. 
11 Sumpio BE. Foot ulcers. N Engl J Med. 2000;343:787-93.

12 Aronow WS. Management of peripheral arterial disease of the lower extremities in elderly patients. J Gerontol A Biol Sci Med Sci. 2004;59:172-7.

13 Jeffcoate WJ, Price P, Harding KG. Wound healing and treatments for people with diabetic foot ulcers. Diabetes Metab Res Rev. 2004;20 (suppl 1):78-89.

14 Dang CN, boulton AJM. Changing perspectives in diabetic foot ulcer management. Lower Extremity Wounds. 2003;2:4-12.

15 Armstrong DG, Lipsky BA. Diabetic foot infections: stepwise medical and surgical management. Int Wound J. 2004;1:123-32.

16 Lipsky BA, Berendt AR, Deery HG. Diagnosis and treatment of diabetic foot infections. Clin Infect Dis. 2004;39:885-910.

17 Miyajima S, Shirai A, Yamamoto S, Okada N, Matsushita T. Risk factors for major limb amputations in diabetic foot gangrene patients. Diabetes Res Clin Pract. 2006;71:272-9.

18 Markowitz JS, Gutterman EM, Magee G, Margolis DJ. Risk of amputation in patients with diabetic foot ulcers: a claims-based study. Wound Repair Regen. 2006;14:11-17.

19 Abbott C, Carrington A, Ashe H. The North-West Diabetes Foot Care Study: incidence of and risk factors for new diabetic foot ulceration in a community-based patient cohort. Diabetic Med. 2002;19:377-84.

20 Moss SE, Klein R, Klein B: The 14-year incidence of lower-extremity amputation in a diabetic population. Diabetes Care. 1999;22:951-9.

21 Proceedings of a consensus development conference on standardized measures in diabetic neuropathy. Diabetes Care. 1992;15:1080-107.

22 Dellon AL. From there to here: a personal viewpoint after three decades of neuropathy research. Clin Podiatr Med Surg. 2006;23:497-508.

23 Valdivia JMV, Dellon AL, Weinand ME, Maloney CT. Surgical treatment of peripheral neuropathy. J Am Podiatr Med Assoc. 2005;95:451-4

24 Aszmann O, Tassler PL, Dellon AL. Changing the natural history of diabetic neuropathy: incidence of ulcer/amputation in the contralateral limb of patients with a unilateral nerve decompression procedure. Ann Plastic Surg. 2004;53:517-22.

25 Mayfield JA, Reiber GE, Sanders LJ, Janisse D, Pogach LM, American Diabetes Association. Preventive foot care in diabetes. Diabetes Care. 2004;27 (suppl 1):63-4.

26 Mayfield JA, Reiber GE, Sanders LJ, Janisse D, Pogach LM, American Diabetes Association. Preventive foot care in people with diabetes. Diabetes Care. 2003;26 (suppl 1):78-9.

27 Bowering CK. Diabetic foot ulcers: pathophysiology, assessment, and therapy. Can Fam Phys. 2001;47:1007-16.

28 Laird JR, Zeller T, Gray BH. Limb salvage following laser-assisted angioplasty for critical limb ischemia: results of the LACI multicenter trial. J Endovasc Ther. 2006;13:1-11.

29 Mousa A, Rhee JY, Trocciola SM. Percutaneous endovascular treatment for chronic limb ischemia. Ann Vasc Surg. 2005;19:186-91

30 Trocciola SM, Chaer R, Dayal R. Comparison of results in endovascular interventions for infrainguinal lesions: claudication versus critical limb ischemia. Am Surg. 2005;71:474-9.
31 Wood WA, Wood MA, Werter AS, Menn JJ, Hamilton AS, Jacoby R, Dellon AL. Testing for loss of protective sensation in patients with foot ulceration. J Am Podiatr Med Assoc. 2005;95:469-74

32 Tassler PL, Dellon AL, Scheffler NM. Computer-assisted measurement in diabetic patients with and without foot ulceration. J Am Podiatr Med Assoc. 1995;85:679-84.

33 Ferreira MC, Rodrigues L, Fels KW. New method for evaluation of cutaneous sensibility in diabetic feet: preliminary report. Clinics. 2004;59:286-90.

34 Brem H, Sheehan P, Boulton AJ. Protocol for treatment of diabetic foot ulcers. Am J Surg. 2004;187(suppl 5):1-10

35 Hess CT, Kirsner RS. Orchestrating wound healing: assessing and preparing the wound bed. Adv Skin Wound Care. 2003;16:246-57.

36 Saap LJ, Falanga V. Debridment performance index and its correlation with complete closure of diabetic foot ulcers. Wound Repair Regen. 2002;10:354-9.

37 Sibbald RG, Orsted H, Schultz GS, coutts P, Kest D. Preparing the wound bed 2003: focus on infection and inflammation. Ostomy Wound Management. 2003;49:23-51.

38 Sibbald RG, Williamson D, Orsted HL. Preparing the wound bed debridement, bacterial balance, and moisture balance. Ostomy Wound Manage. 2000;46:14-22,24-28,30-5.

39 Falanga V. Wound healing and its impairment in the diabetic foot. Lancet. 2005;366:1736-43.

40 Eldor R, Raz I, bem Yehuda A, Boulton AJ. New and experimenta approaches to treatment of diabetic foot ulcers: comprehensive review of emerging treatment strategies. Diabet Med. 2004;21:116173.

41 Andros G, Armstrong DG, Attinger CE, Boulton AJ, Frykberg RG, Joseph WS, et al. Consensus statement on negative pressure wound therapy (V.A. C. therapy) for the management of diabetic foot wounds. Ostomy Wound Manage. 2006;Jun (suppl):1-32.

42 Armstrong DG, Lavery LA. Negative pressure wound therapy after partial diabetic foot amputation: a multicentre, randomized controlled trial. Lancet. 2005:366:1704-10.

43 Eginton MT, brown KR, Seabrook GR. A prospective randomized evaluation of negative-pressure wound dressing for diabetic foot wounds. Ann Vasc Surg. 2003;17:645-9.

44 Silverstein G. Dermal regeneration template in the surgical management of diabetic foot ulcers: a series of five cases. J Foot Ankle Surg. 2006; $45: 28-33$

45 Puttirutvong P. Meshed skin graft versus split thickness skin graft in diabetic ulcer coverage. J Med Assoc Thai. 2004;87:66-72.

46 Roukis TS, Zgonis T. Skin grafting techniques for soft-tissue coverage of diabetic foot and ankle wounds. J Wound Care. 2005;14:173-6.

47 Attinger CE, Ducic I, Cooper P. The role of intrinsic muscle flaps on the foot for bone coverage in foot and ankle defects in diabetic and nondiabetic patients. Plast Reconstr Surg. 2002;110:1047-54.

48 Osiogo FO, Lai CS, Wang WH, Chye YF, Lin SD. Retrospective review of free gracilis muscle flaps in the management of nonhealing diabetic foot ulceration. J Foot Ankle Surg. 2006;45:252-60. 
49 Argenta LC, Morykwas MJ, Marks MW, DeFranzo AJ, Molnar JA, Davi LR. Vacuum-assisted closure: state of clinic art. Plast Reconstr Surg. 2006;117 (Suppl 7):127-42.

50 Ducic I, Hung V, Dellon AL. Innervated free flaps for foot reconstruction: a review. J Reconstr Microsurg. 2006;22:433-42.

51 Yang WG, Chiang YC, Wei FC, Feng GM, Chen KT. Thin anterolateral thigh perforator flap using a modified perforator microdissection technique and its clinical application for foot resurfacing. Plast Reconstr Surg. 2006;117:1004-8.

52 Ozkan O, Coskunfirat OK, Ozgentas HE. Reliability of free-flap coverage in diabetic foot ulcers. Microsurgery. 2005;25:107-12

53 Rainer C, Schwabegger AH, Meirer R, Perkmann R, Ninkovic M. Microsurgical management of the diabetic foot. J Reconstr Microsurg. $2003 ; 19: 543-53$

54 Jeffcoate WJ, Lipsky BA. Controversies in diagnosing and managing osteomyelitis of the foot in diabetes. Clin Infect Dis. 2004;39(suppl 2):115-22.

55 Gordois A, Scuffham P, Shearer A, Oglesby A, Tobian JA. The health care costs of diabetic peripheral neuropathy in the U. S. Diabetes Care $2003 ; 26: 1790-5$

56 Ramsey SD, Newton K, Blough D, McCulloch DK, Sandhu N, Reiber $\mathrm{GE}$, et al. Incidence, outcomes, and cost of foot ulcers in patients with diabetes. Diabetes Care. 1999;22:382-7.

57 Benbow M. Guidelines for the prevention and treatment of pressure ulcers. Nurs Stand. 2006;20:42-4.

58 Lindgren M, Malmqvist LA, Sjoberg F, Ek AC. Altered skin blood perfusion in areas with non blanchable erythema: an explorative study. Int Wound J. 2006;3:215-23

59 Cullum N, Nelson EA, Nixon J. Pressure ulcers. Clin Evid. 2006;15:2592-606

60 Xakellis GC, Frantz RA. The cost of healing pressure ulcers across multiple health care settings. Adv Wound Care. 1996;9:18-22.

61 Bryant RA, Shannon ML, Pieper B, Braden BJ, Morris DJ. Pressure ulcers. In: Bryant RA. Acute and chronic wounds - nursing management. Missouri: Mosby; 1992. p. 105-63.

62 Bergstrom N, Braden BJ, Kemp M, Champagne M, Ruby E. Multi-site study of incidence of pressure ulcers and the relationship between risk level, demographic characteristics, diagnoses, and prescription of preventive interventions. J Am Geriatric Soc. 1996;44:22-30.

63 Rogenski NMB, Santos VLCG. Incidence of pressure ulcers at a university hospital. Rev Latino-Am Enfermagem. 2005;13:474-80.

64 Ferreira MC, Wada A, Tuma Jr P. The vacuum assisted closure of complex wounds. Clinics. 2003;58:227-30.

65 Costa MP, Sturtz G, Costa FPP, Ferreira MC; Barros-Filho TEP Epidemiologia e tratamento das úlceras de pressão: experiência de 77 casos. Acta Ortop Bras. 2005;3:124-33.

66 Paranhos WY, Santos VLCG. Avaliação do risco para úlceras por pressão por meio da Escala de Braden na língua portuguesa. Rev Esc Enfermagem USP. 1999;33:191-206.

67 Quintal D, Jackson R. Leg ulcers: a historical perspective. Clin Dermatol. 1990;8:4-12.
68 Jones J, Barr W, Robinson J, Carlisle C. Depression in patients with chronic venous ulceration. Br J Nurs. 2006;15:S17-23.

69 Nélzen O, Bergqvist D, Lindhagen A, Hallbook T. Chronic leg ulcers: an underestimated problem in primary health care among elderly patients. J Epidemiol Community Health. 1991;45:184-7.

70 Abbade LP, Lastoria S. Venous ulcer: epidemiology, physiopathology, diagnosis and treatment. Int J Dermatol. 2005;44:449-56.

71 Hume M. Venous ulcers, the vascular surgeon, and the Medicare budget. J Vasc Surg 1992;16:671-3

72 White JV, Ryjewski C. Chronic venous insufficiency. Perspect Vasc Surg Endovasc Ther. 2005;17:319-27.

73 Hach-Wunderle V, Hach W. Invasive therapeutic options in truncal varicosity of the great saphenous vein. Vasa. 2006;35:157-66.

74 Wollina U, Abdel-Naser MB, Mani R. A review of the microcirculation in skin in patients with chronic venous insufficiency: the problem and the evidence available for therapeutic options. Int J Low Extrem Wounds. 2006;5:169-80.

75 Myers K, Fris R, Jolley D. Treatment of varicose veins by endovenous laser therapy: assessment of results by ultrasound surveillance. Med J Aust. 2006;185:199-202.

76 Steed DL, Hill DP, Woodske ME, Payne WG, Robson MC. Woundhealing trajectories as outcome measures of venous stasis ulcer treatment. Int Wound J. 2006;3:40-7.

77 Iglesias C, Nelson EA, Cullum NA,Torgerson DJ, et al. VenUS I: a randomised controlled trial of two types of bandage for treating venous leg ulcers. Health Technol Assess. 2004;8:101-5.

78 DePalma RG. Surgical treatment of chronic venous ulceration. In: Bergan JJ, Yao JST, eds. Venous Disorders. Philadelphia: WB Saunders; 1991. p. 396-406.

79 Weinzweig N, Schuler J. Free tissue transfer in treatment of the recalcitrant chronic venous ulcer. Ann Plast Surg. 1997;38:611-9.

80 Abbade LP, Lastoria S, Almeida RH, Stolf HO. A sociodemographic, clinical study of patients with venous ulcer. Int J Dermatol. 2005;44:989-92.

81 Baker SR, Stacey MC, Joop-McKay AG, Hoskin SE, Thompson PJ. Epidemiology of chronic venous ulcers. Br J Surg. 1991:78:864-7.

82 Nélzen O, Bergqvist D, Lindhagen A. Venous and non-venous leg ulcers: clinical history and appearance in a population study. Br J Surg. 1994;81:182-7.

83 Vowden KR, Vowden P. Preventing venous ulcer recurrence: a review. Int Wound J. 2006:3:11-21.

84 Ruckley CV. Socioeconomic impact of chronic venous insufficiency and leg ulcers. Angiology. 1997:48:67-9.

85 Bergan JJ, Sparks SR. Non-elastic compression: an alternative in management of chronic venous insufficiency. J Wound Ostomy Continence Nurs. 2000;27:83-9

86 Khan MN, Davies CG. Advances in the management of leg ulcers- the potential role of growth factors. Int Wound J. 2006;3:113-20.

87 Prince S, Dodds SR. Use of ulcer size and initial responses to treatment to predict the healing time of leg ulcers. J Wound Care. 2006;15:299303. 
88 Palfreyman SJ, Nelson EA, Lochiel R, Michaels JA. Dressings for healing venous leg ulcers. Cochrane Database Syst Rev. 2006;9;3:CD001103.

89 Bechara FG, Sand M, Sand D, Stucker M, Altmeyer P, Hoffmann K. Shave therapy for chronic venous ulcers: a guideline for surgical management and postoperative wound care. Plast Surg Nurs. 2006;26:29-34.

90 Jones JE, Nelson EA. Skin grafting for venous leg ulcers. Cochrane Database Syst Rev. 2000;2:CD001737.

91 Trent JT, Falabella A, Eaglstein WH, Kirsner RS. Venous ulcers: pathophysiology and treatment options. Ostomy Wound Manage. 2005;51:38-54.

92 Top H, Benlier E, Aygit C, Kiyak M. Distally based sural flap in treatment of chronic venous ulcers. Ann Plast Surg. 2005;55:160-5.

93 Weinzweig N. Invited discussion: Distally based sural flap in treatment of chronic venous ulcers. Ann Plast Surg. 2005;55:166-8.

94 Norton KS, Johnson LW, Perry T, Perry KH, Sehon JK, Zibari GB. Management of Fournier's gangrene: an eleven year retrospective analysis of early recognition, diagnosis, and treatment. Am Surg. 2002;68:709-13.

95 Harper D, Banwell PE. Fournier's gangrene exposed. Int Wound J. $2004 ; 1: 78-9$
96 Korhonen K. Hyperbaric oxygen therapy in acute necrotizing infections. With a special reference to the effects on tissue gas tensions. Ann Chir Gynaecol. 2000;89:7-36

97 Steinman E, Utiyama EM, Maximiniano LF, Belivacqua RG, Birolini D. Fournier syndrome: evaluation and initial treatment. Rev Assoc Med Bras. 1992;38:209-13.

98 Anadrade AC, Amarante MT, Ferreira MC, Lodovici O. Tratamento cirúrgico na seqüela da síndrome de Fournier. Rev Assoc Méd Brás. 1991;37:22-6.

99 Coelho S, Amarelo M, Ryan S, Reddy M, Sibbald RG. Rheumatoid arthritis associated inflammatory leg ulcers: a new treatment for recalcitrant wounds. Int Wound J. 2004;1:81-4.

100 Drücke D, Daigeler A, Lehnhardt M, Hauser V, Steinau HU. Plastischchirurgische Defektdeckung bei immunsupprimierten Patienten-heilt es wirklich sclechter? Plastische Chirurgie. 2005;10:127-32.

101 Eulufí AM, Calderón WO, Piñeros JLB, Silva MC, Cuadra A C, Léniz PM, et al. Pioderma gangrenosa en cirugía plástica: Comunicación de tres casos. Rev Méd Chile. 2006;134:339-44.

102 Crowson N, Mihm Jr M, Magro CM. Pyoderma gangrenosum: a review. J Cutan Pathol. 2003;30:97-107.

103 Gottrup F. Optimizing wound treatment through health care structuring and professional education. Wound Repair Regen. 2004;12:129-33. 